\title{
Pengaruh Pemberian Susu Tinggi Protein terhadap Tingkat Nafsu Makan dan Kadar Glukosa Postprandial
}

\author{
Effect of High Protein Milk on Appetite Level and Postprandial \\ Blood Glucose
}

\author{
Harna $^{1 *}$, Clara M.Kusharto ${ }^{2}$, Katrin Roosita ${ }^{2}$, Andi Muh Asrul Irawan ${ }^{3}$ \\ ${ }^{1}$ Program Studi Gizi Fakultas Ilmu-Ilmu Kesehatan Universitas Esa Unggul \\ ${ }^{2}$ Departemen Ilmu Gizi Fakultas Ekologi Manusia Institut Pertanian Bogor \\ ${ }^{3}$ Program Studi Gizi Fakultas Sains dan Teknologi Universitas Al Azhar Indonesia \\ ("harna@esaunggul.ac.id)
}

\begin{abstract}
ABSTRAK
Susu tinggi protein merupakan makanan kompleks yang mengandung beberapa senyawa bioaktif yang potensial memiliki efek terhadap nafsu makan. Namun, mekanisme susu tinggi protein terhadap nafsu makan masih kurang dipahami pada orang dewasa dengan berat badan kurang. Penelitian bertujuan menganalisis pengaruh susu protein tinggi terhadap tingkat nafsu makan dan glukosa postprandial. Penelitian menggunakan experimental trial desain randomized controlled trial. Subjek dibagi menjadi dua kelompok, yaitu 24 subjek pada kelompok perlakuan dan 23 subjek pada kelompok kontrol. Kelompok perlakuan diberi susu tinggi protein dan kelompok kontrol diberi glukosa. Tingkat nafsu makan meliputi tingkat kelaparan, kepuasan, dan keinginan untuk makan dievaluasi menggunakan Visual Analogue Scale (VAS), yang dianalisis dalam incremental Area Under the Curve (iAUC). Hasil penelitian menunjukkan bahwa ada peningkatan yang signifikan nilai iAUC tingkat rasa lapar pada kelompok perlakuan dibandingkan dengan kontrol $(\mathrm{p}<0,05)$, dengan $8881 \pm 638,4$ min.mm kelompok perlakuan dan 7297,8 $\pm 439,6$ min.mm kelompok kontrol. Tidak ada perbedaan yang signifikan pada tingkat kepuasan dan keinginan untuk makan antara kedua kelompok $(\mathrm{p}>0,05)$. Kadar glukosa postprandial pada kelompok perlakuan signifikan $(\mathrm{p}<0,05)$ lebih rendah dibandingkan dengan kelompok kontrol. Penelitian ini menyimpulkan bahwa intervensi susu tinggi protein kemungkinan dapat meningkatkan tingkat rasa lapar pada orang dewasa dengan berat badan kurang.
\end{abstract}

Kata kunci : Kelaparan, kepuasan, Visual Analogue Scale

\section{ABSTRACT}

High protein milk is a complex food that contains several potential bioactive compounds that might effect on appetite control. However, the mechanism of high protein milk effect on appetite is still poorly understood in underweight adults. This study aimed to analyze the effect of high protein milk on appetite level and postprandial glucose. This study used experimental trial with design randomized controlled trial. The subjects were divided into two groups, 24 subjects in the treatment group and 23 subjects in the control group. Treatment group was given high protein milk and control group was given glucose. Subjective feelings including hunger, satisfaction, and desire to eat were evaluated using Visual Analogue Scale (VAS), which is analyzed in the incremental Area Under the Curve (iAUC). The results showed that there was a significant increase in iAUC value of hunger level in the treatment group compared with control ( $p<0.05)$, 8881 \pm 638.4 min.mm treatment group and $7297.8 \pm 439.6 \mathrm{~min}$. $\mathrm{mm}$ control group. There was no significant difference in the level of satisfaction and desire to eat between the two groups $(p>0.05)$. Postprandial glucose levels in the treatment group were significantly $(p<0.05)$ lower than the control group. The study concluded that high protein milk intervention was increase hunger levels in underweight adults.

Keywords : Hunger, satisfaction, Visual Analogue Scale 


\section{PENDAHULUAN}

Susu tinggi protein mengandung dua komponen protein utama yaitu protein whey dan kasein. Kasein dan whey memiliki sifat fisikokimia dan biologis yang unik. ${ }^{1}$ Kandungan kasein pada protein susu mencapai $80 \%$ dari jumlah protein yang terdapat dalam susu sapi, sedangkan kandungan protein whey pada susu sebanyak $20 \%{ }^{2}$ Komponen biologis dari protein whey yaitu $\alpha$-lactalbumin $(\alpha-\mathrm{LA}, 20 \%), \beta$-lactoglobulin $(\beta-\mathrm{Lg}$, $50 \%$ ), serum albumin (Bovine Serum Albumin, $10 \%$ ), immunoglobulins $(10 \%)$ dan peptones protease $(<10 \%) .{ }^{1,3}$

Data epidemologi menunjukkan bahwa konsumsi susu tinggi protein dikaitkan dengan penurunan prevalensi gangguan metabolik atau mempertahankan kesehatan metabolik. ${ }^{4,5}$ Konsumsi susu yang mengandung protein dapat menstimulasi sekresi insulin. Insulin memiliki efek langsung dan tidak langsung pada metabolisme karbohidrat, lemak, protein, termasuk stimulasi penyerapan glukosa, sintesis glikogen, penyerapan lipid dan sintesis trigliserida, protein sintesis dan menghambat pemecahan protein, lipolisis dan glukoneogenesis. Oleh karena itu, stimulasi sekresi oleh protein susu berkontribusi terhadap efek metabolik pada jaringan dan berperan dalam anabolisme massa otot. ${ }^{6}$

Respon insulin setelah mengonsumsi susu tinggi protein telah dibuktikan pada beberapa penelitian. Hal ini menunjukkan bahwa protein pada susu terutama protein whey memiliki potensi sebagai insulinotropik. Mekanisme insulinotropik dari protein susu kemungkinan disebabkan oleh kandungan peptide bioaktif, asam amino spesifik, dan aktivasi hormon inkretin (terutama Gastric inhibitory polypeptide) yang dilepaskan pada saat mengonsumsi protein whey. ${ }^{7,8}$ Kandungan $\alpha$-LA dalam protein susu memiliki komposisi asam amino sulfur sistein $(6 \%)$ dan telah terbukti bahwa mengonsumsi protein whey pada susu yang mengandung sistein dapat menurunkan respon glukosa postprandial melalui perbaikan status Growth-Stimulating Hormone (GSH) dan memperbaiki resistensi insulin pada tikus yang diberikan tinggi sukrosa. ${ }^{9}$ Pengaturan glukosa postprandial penting untuk meminimalkan peningkatan glukosa darah terhadap makanan pada individu yang sehat maupun penderita Diabetes Melitus tipe 2. Salah satu manfaat protein susu yaitu merangsang pelepasan insulin dan memiliki potensi mengubah uptake glukosa dalam jaringan dan menekan fluktuasi glukosa darah postprandial. ${ }^{4,10}$

Penelitian yang dilakukan oleh Frid et al. mengemukakan bahwa pemberian protein pada susu (18 gram) ke dalam makanan yang mengandung karbohidrat lebih cepat dicerna dan diserap, mengakibatkan peningkatan konsentrasi plasma insulin dan menurunkan glukosa postprandial. ${ }^{11}$ Protein whey lebih cepat masuk ke dalam jejunum dibandingkan dengan kasein, terutama dalam bentuk peptida terdegradasi. ${ }^{12,13}$ Beberapa penelitian menunjukkan bahwa protein pada susu memiliki efek yang lebih baik dalam mengontrol nafsu makan dalam jangka pendek. ${ }^{14}$

Efek protein dalam pengaturan nafsu makan disebabkan oleh tingkat pengosongan lambung dan peningkatan asam amino pada saat postprandial. ${ }^{4,15}$ Selain itu, indeks massa tubuh dapat menentukan efek protein pada susu terutama protein whey terhadap tingkat nafsu makan. Penelitian yang dilakukan oleh Bowen et al. menunjukkan bahwa pemberian protein susu dalam bentuk whey memiliki respon rasa lapar yang berbeda terhadap subjek yang memiliki berat badan normal dan berat badan lebih. Protein yang diberikan pada subjek yang memiliki berat badan lebih dapat menekan rasa lapar dibandingkan dengan subjek yang memiliki berat badan normal, hal ini dibuktikan dengan peningkatan hormon Glukagon Like Peptide-1 (GLP-1) yang signifikan pada subjek overweight dibanding subjek normal. ${ }^{16}$ Namun, belum ada penelitian mengenai efek susu tinggi protein terhadap tingkat nafsu makan dan glukosa postprandial pada usia dewasa dengan status gizi kurang. Tujuan penelitian ini yaitu untuk menganalisis efek pemberian susu tinggi protein terhadap tingkat nafsu makan dan glukosa postprandial pada usia dewasa dengan status gizi kurang.

\section{BAHAN DAN METODE}

Penelitian ini merupakan experimental trial dengan desain adalah randomized controlled trial (RCT). Penelitian ini telah mendapat persetujuan etik dari Komite Etik Penelitian Universitas Indonesia Fakultas Kedokteran. Bahan yang digunakan dalam penelitian ini adalah produk susu Appeton, merupakan produk susu tinggi protein yang me- 
ngandung protein lengkap. Populasi dalam penelitian ini adalah mahasiswa IPB. Berdasarkan hasil penelitian yang dilakukan Kawase et al. tahun 2000 dengan nilai standar deviasi $\sigma=1.55$. Perubahan perlakuan kontrol adalah $(\mu 2)=4.3$ dan perlakuan pemberian susu $(\mu 1)$ adalah $(\mu 1)=5.5$. Nilai $\alpha=0.05$, dan power test sebesar $1-\beta=0.80$, kemudian disubstitusikan ke dalam rumus Lamsehow, diperoleh sampel minimal 23 untuk masingmasing kelompok. ${ }^{17}$ Kriteria inklusi yaitu status gizi kurang, sehat dan tidak mengonsumsi suplemen penambah nafsu makan.

Penelitian ini terbagi menjadi dua kelompok perlakuan dan kelompok kontrol. Subjek pada kelompok perlakuan diberikan sarapan roti yang nilai gizinya sudah terstandar (Energi $330 \mathrm{kkal}$, KH 40 gr, protein 5 gr, lemak 10 gr, dan serat 2 gr) dan susu tinggi protein sebanyak 50 gram dengan kandungan zat gizi energi $200 \mathrm{kkal}, \mathrm{KH}$ 26 gr, protein 15 gr, lemak 5 gr. Pada kelompok kontrol diberikan sarapan roti dan glukosa murni. Kelompok perlakuan dan kontrol hanya berbeda pada pemberian susu tinggi protein dan glukosa. Subjek berpuasa selama 10-12 jam, pengambilan data tingkat nafsu makan dimulai pada pukul 08.00 WIB sampai 11.00 WIB, selama pengambilan data hanya boleh mengonsumsi air putih. Penelitian ini merupakan penelitian bersifat akut, maka intervensi yang diberikan hanya sekali selama proses penelitian. Selama proses pengambilan data berlangsung, peneliti mengawasi responden agar tidak mengonsumsi makanan selain intervensi yang diberikan.

Data yang dikumpulkan meliputi karakteristik sampel dan instrumen yang digunakan yaitu kuesioner, timbangan, dan microtoise. Pengukuran tingkat nafsu makan menggunakan metode Visual Analog Scale (VAS) dan subjek melaporkan tingkat nafsu makan mereka pada menit 0 sebelum diberikan sarapan, kemudian diberikan waktu 15 menit untuk mengonsumsi makanan yang diberikan. Setelah 15 menit selesai makan, dilakukan pengukuran VAS pada menit 40, 55, 70, 85, 115 dan 145. Ada tiga jenis tingkat nafsu makan yang dinilai dalam penelitian ini, yaitu tingkat kelaparan (Bagaimana perasaan lapar anda saat ini? Saya tidak sama sekali lapar - Saya sangat lapar), tingkat kepuasan (Bagaimana tingkat kepuasan anda saat ini? Saya tidak merasa puas sama sekali-saya merasa sangat puas), dan tingkat keinginan untuk makan (seberapa kuat keinginan anda untuk makan saat ini? Saya tidak memiliki keinginan untuk makan sama sekali - keinginan saya untuk makan sangat kuat). Subjek membuat tanda vertikal antara dua ekstremitas, sesuai dengan apa yang mereka rasakan saat VAS diberikan, metode ini diadopsi dari penelitian yang dilakukan oleh Olli et al tahun 2015. ${ }^{18}$

Pengolahan dan analisis data menggunakan Microsoft Excel 2010 dan program SPSS 16. Analisis data yang pertama dilakukan adalah pengukuran deskriptif terhadap beberapa parameter seperti karakteristik individu. Beberapa ukuran yang dianalisis antara lain mean (rata-rata) dan standar deviasi. Tingkat nafsu makan dibagi menjadi tiga yaitu tingkat kelaparan, tingkat kepuasan dan keinginan untuk makan akan dinyatakan dalam incremental areas under the curce (iAUC). Nilai iAUC dihitung dengan menggunakan metode Trapezoid. Kurva tingkat nafsu makan dimulai dengan titik nol, berlanjut pada menit ke 40 (pasca makan) dan berakhir pada menit 145. iAUC dinyatakan dalam min.mm dan hasil iAUC pada masing-masing periode untuk kelompok intervensi dan kontrol dibandingkan dengan menggunakan independent T-test. Uji one way ANOVA digunakan untuk analisis hubungan antar variabel dalam satu arah dan dilanjutkan uji lanjut duncan jika ada perbedaan.

\section{HASIL}

Karakteristik subjek yang diamati pada penelitian ini adalah jenis kelamin, usia, berat badan, dan tinggi badan. Sebagian besar subjek yaitu perempuan sebanyak $62,5 \%$ pada kelompok perlakuan dan $82,6 \%$ pada kelompok kontrol. Jenis kelamin subjek antar kelompok tidak berbeda signifikan ( $p>0,05)$. Usia subjek dalam penelitian ini yaitu kelompok usia dewasa muda dengan kisaran usia 18-30 tahun. Sebagian besar usia subjek yaitu antara 18-24 tahun, 79,2\% pada kelompok perlakuan dan 95,7\% pada kelompok kontrol (Tabel 1).

Hasil uji independent t-test menunjukkan bahwa tidak ada perbedaan signifikan usia pada kelompok kontrol dan perlakuan $(p>0,05)$. Sesuai dengan kriteria inklusi yang telah ditetapkan bahwa subjek harus berada dalam kategori status gizi 
Tabel 1. Karakterstik Subjek Penelitian

\begin{tabular}{|c|c|c|c|}
\hline \multirow[b]{2}{*}{ Variabel } & \multicolumn{2}{|c|}{ Kelompok } & \multirow[b]{2}{*}{$\mathbf{p}^{*}$} \\
\hline & $\begin{array}{c}\text { Perlakuan } \\
\text { n(\%) }\end{array}$ & $\begin{array}{c}\text { Kontrol } \\
\text { n(\%) }\end{array}$ & \\
\hline \multicolumn{4}{|l|}{ Jenis Kelamin ${ }^{* *}$} \\
\hline Laki-laki & $9(37.5)$ & $4(17.4)$ & 0.12 \\
\hline Perempuan & $15(62.5)$ & $19(82.6)$ & \\
\hline Usia (tahun) & $22.7 \pm 2.2$ & $22.3 \pm 1.9$ & 0.46 \\
\hline $18-24$ & $19(79.2)$ & $22(95.7)$ & \\
\hline $25-30$ & $5(20.8)$ & $1(4.3)$ & \\
\hline Status Gizi $\left(\mathrm{kg} / \mathrm{m}^{2}\right)$ & $17.02 \pm 0.96$ & $17.56 \pm 0.65$ & 0.59 \\
\hline
\end{tabular}

"Uji independent T-test ; **Uji Mann-Whitney

Tabel 2. Rerata Perubahan Tingkat Nafsu Makan Subjek pada Kedua Kelompok

\begin{tabular}{|c|c|c|c|c|c|c|c|c|}
\hline \multirow{2}{*}{ Kelompok } & \multicolumn{7}{|c|}{ Waktu (menit) } & \multirow{2}{*}{$\mathbf{p}^{1}$} \\
\hline & $\mathbf{0}$ & 40 & 55 & 70 & 85 & 115 & 145 & \\
\hline \multicolumn{9}{|l|}{ Tingkat Rasa } \\
\hline \multicolumn{9}{|l|}{ Lapar } \\
\hline Perlakuan & $74.5 \pm 18.7^{\mathrm{a}}$ & $56 \pm 26^{\mathrm{b}}$ & $56.7 \pm 24^{b}$ & $55.8 \pm 25^{\mathrm{b}}$ & $56.9 \pm 26^{b}$ & $61.4 \pm 24^{\mathrm{ab}}$ & $68 \pm 26^{\mathrm{ab}}$ & 0.064 \\
\hline Kontrol & $67.3 \pm 22.7^{\mathrm{a}}$ & $40 \pm 24^{\mathrm{b}}$ & $41.7 \pm 22^{b}$ & $44.8 \pm 22^{\mathrm{bc}}$ & $51.2 \pm 19^{\mathrm{bc}}$ & $57 \pm 17.6^{\mathrm{ac}}$ & $66 \pm 16^{\mathrm{a}}$ & $0.000^{*}$ \\
\hline $\mathrm{p}^{2}$ & 0.242 & 0.028 & $0.03 *$ & 0.119 & 0.398 & 0.487 & 0.879 & \\
\hline \multicolumn{9}{|c|}{ Tingkat Kepuasan } \\
\hline Perlakuan & $19 \pm 25^{\mathrm{a}}$ & $53 \pm 27.5^{\mathrm{b}}$ & $52 \pm 26^{b}$ & $48 \pm 23^{b}$ & $48 \pm 25^{b}$ & $45 \pm 23^{b}$ & $43 \pm 25^{b}$ & $0.000^{*}$ \\
\hline Kontrol & $5 \pm 14^{\mathrm{a}}$ & $48.5 \pm 24^{b}$ & $47 \pm 20^{b}$ & $46 \pm 21^{b}$ & $43 \pm 23^{b}$ & $40 \pm 2^{0 \mathrm{~b}}$ & $38 \pm 22^{b}$ & $0.000^{*}$ \\
\hline $\mathrm{p}^{2}$ & 0.023 & 0.571 & 0.431 & 0.721 & 0.490 & 0.430 & 0.451 & \\
\hline \multicolumn{9}{|c|}{$\begin{array}{l}\text { Tingkat Keinginan } \\
\text { untuk makan }\end{array}$} \\
\hline Perlakuan & $77 \pm 23^{a}$ & $59 \pm 29^{b}$ & $58 \pm 27^{b}$ & $58 \pm 27^{b}$ & $61 \pm 27^{\mathrm{ab}}$ & $63 \pm 24^{\mathrm{ab}}$ & $70 \pm 26^{\mathrm{ab}}$ & 0.108 \\
\hline Kontrol & $76 \pm 23^{a}$ & $58 \pm 31^{\mathrm{b}}$ & $57.8 \pm 28^{b}$ & $56 \pm 27^{b}$ & $60 \pm 26^{\mathrm{ab}}$ & $65 \pm 24.3^{\mathrm{ab}}$ & $67 \pm 27^{\mathrm{ab}}$ & 0.164 \\
\hline $\mathrm{p}^{2}$ & 0.079 & 0.057 & 0.047 & 0.105 & 0.184 & 0.590 & 0.587 & \\
\hline
\end{tabular}

1) uji one way ANOVA; 2) uji paired t-test; Pada baris yang sama, angka dengan huruf sama menunjukkan tidak terdapat perbedaan yang nyata antar kelompok $(\mathrm{p}>0.05) ;$ *Signifikan dengan $\mathrm{p}<0.05$

kurang, sehingga kisaran IMT subjek dalam penelitan ini yaitu $16-18.5 \mathrm{~kg} / \mathrm{m}^{2}$. Rerata berat badan subjek pada kelompok perlakuan yaitu 44,4 kg dan 43,7 kg pada kelompok kontrol. Hasil uji independent $t$-test menunjukkan bahwa tidak ada perbedaan signifikan berat badan pada kelompok kontrol dan perlakuan $(\mathrm{p}>0,05)$. Rerata tinggi badan subjek yaitu $161 \mathrm{~cm}$ pada kelompok perlakuan dan $157,6 \mathrm{~cm}$ pada kelompok kontrol, tidak ada perbedaan tinggi badan antara dua kelompok $(\mathrm{p}>0,05)$ (Tabel 1).

Sebelum diberikan perlakuan pada setiap kelompok, subjek mengukur tingkat rasa lapar pada menit ke-0. Setelah mengonsumsi bahan intervensi yang diberikan, menunjukkan bahwa terjadi penurunan rasa lapar yang signifikan pada kedua kelompok $(\mathrm{p}<0,05)$ dititik pengukuran kedua (menit ke-40). Hasil analisis uji one way
ANOVA menunjukkan bahwa tidak terdapat perbedaan signifikan tingkat rasa lapar pada kelompok perlakuan. Hasil uji lanjut duncan dapat diketahui bahwa tidak terdapat perbedaan rasa lapar pada menit ke 40, 45, 55, 70, 85, 115 dan 145 , tetapi rerata tingkat rasa lapar pada menit ke115 tidak berbeda signifikan dengan rerata pada menit ke- 0 . Hal ini menunjukkan bahwa pemberian susu tinggi protein dapat mempertahankan rasa lapar hingga menit ke-115. Terdapat perbedaan signifikan rerata tingkat rasa lapar pada kelompok kontrol $(\mathrm{p}<0.05)($ Tabel 2).

Hasil uji lanjut duncan menunjukkan bahwa terdapat perbedaan signifikan tingkat rasa lapar antara menit ke- 0 (pre meal) dan menit ke-40 (post meal), pada menit ke-40, 55, dan 70 tidak berbeda nyata. Namun, pada menit ke- 85 berbeda nyata dibandingkan dengan menit ke-40. Hal ini menun- 
jukkan bahwa rasa lapar pada kelompok kontrol mengalami peningkatan pada menit ke-85. Meskipun, rerata tingkat rasa lapar pada kelompok perlakuan bisa bertahan hingga menit ke-115 dibandingkan dengan kontrol pada menit ke-85, tetapi rerata tingkat rasa lapar pada setiap menit lebih besar pada kelompok perlakuan dibandingkan kelompok kontrol (Tabel 2). Gambar 1 menunjukkan bahwa terdapat perbedaan signifikan tingkat rasa lapar antara kelompok kontrol dan kelompok perlakuan $(\mathrm{p}=0,049)$, dengan rerata $8881 \pm 638,4$ min.mm dan $7297,8 \pm 439,6$ min.mm. Rerata tingkat rasa lapar pada kelompok perlakuan lebih tinggi dibandingkan dengan kelompok kontrol.

Pada menit ke-0, subjek membuat garis pada skala 0 , sebelum diberikan intervensi. Hasil analisis uji one way ANOVA bahwa terdapat perbedaan signifikan rerata tingkat kepuasan subjek pada kedua kelompok. Hasil uji lanjut duncan diketahui bahwa terdapat perbedaan signifikan antara menit ke- 0 (pre meal) dengan menit ke-40, 55, 70, 85, 115 dan 145 pada kedua kelompok. Tingkat kepuasan tidak berbeda signifikan pada menit ke 55, 70, 85, 115 dan 145 dibandingkan dengan menit ke-40 (post meal) pada kedua kelompok (Tabel 2). Gambar 1 menunjukkan bahwa tidak terdapat perbedaan tingkat kepuasan subjek antara kelompok perlakuan dan subjek $(\mathrm{p}=0,286)$, dengan rerata $6422,96 \pm 616,6$ min.mm kelompok perlakuan dan $5570,83 \pm 485,1$ min.mm kelompok kontrol.

Tabel 2 menunjukkan perubahan rerata tingkat keinginan untuk makan subjek pada setiap kelompok. Hasil analisis uji one way ANOVA menunjukkan bahwa tidak terdapat perbedaan signifikan rerata tingkat keinginan untuk makan pada kedua kelompok ( $>0,05)$. Hasil analisis uji lanjut duncan menunjukkan pada menit ke-40 terjadi penurunan signifikan keinginan untuk makan pada kedua kelompok $(\mathrm{p}<0,05)$ setelah pemberian produk intervensi pada masing-masing kelompok. Tidak terdapat perbedaan signifikan tingkat keinginan untuk makan antara menit ke-40, 55, 70, 85, 115, dan 145 pada kedua kelompok (Tabel 2). Gambar 1 menunjukkan bahwa tidak terdapat perbedaan signifikan keinginan untuk makan subjek antara kelompok perlakuan dan kelompok kontrol $(\mathrm{p}=0,09)$, dengan rerata $9218 \pm 683,7 \mathrm{~min}$.

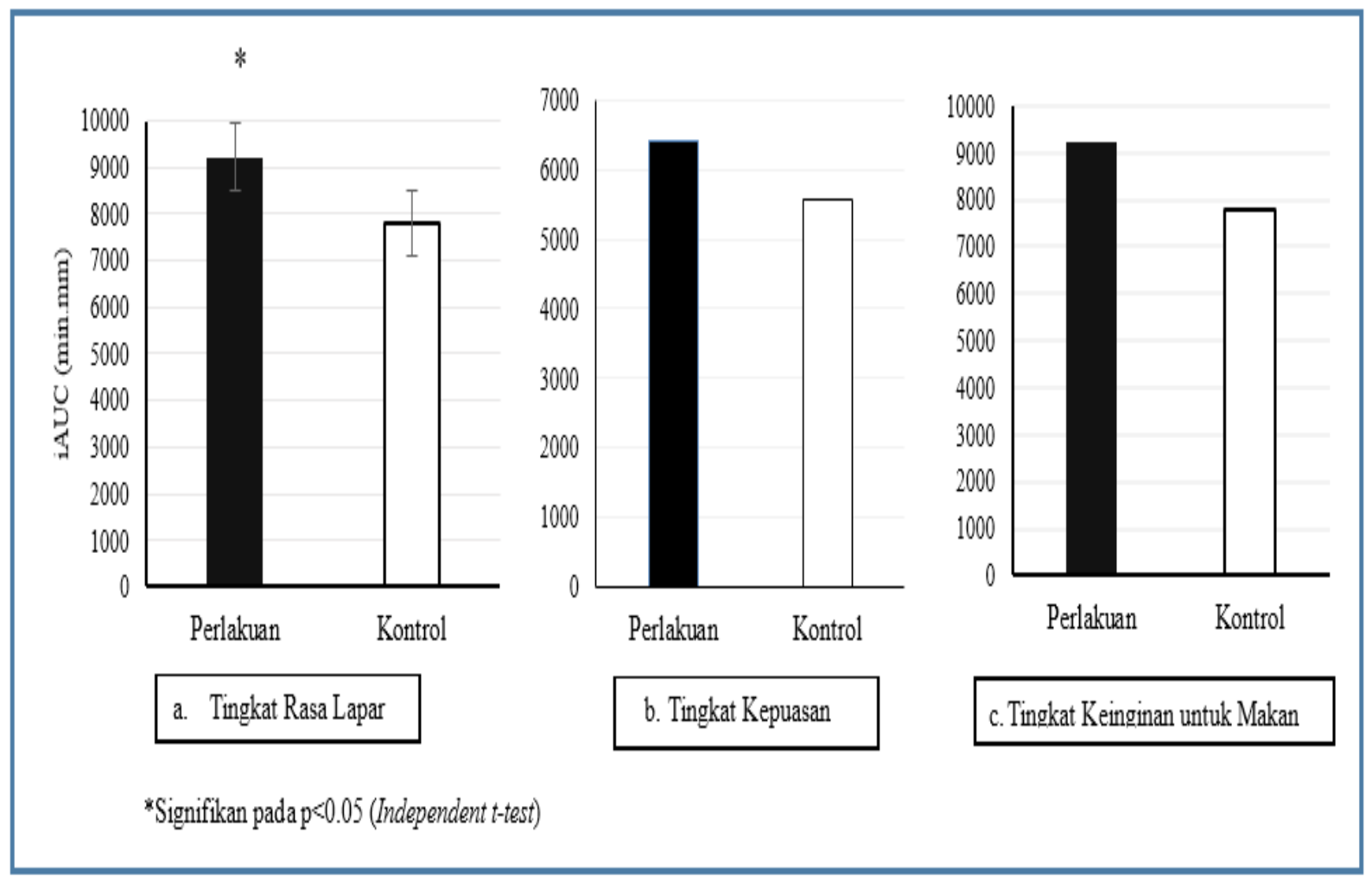

Gambar 1. Rerata Tingkat Nafsu Makan Subjek Dalam iAUC Pada Kedua Kelompok 


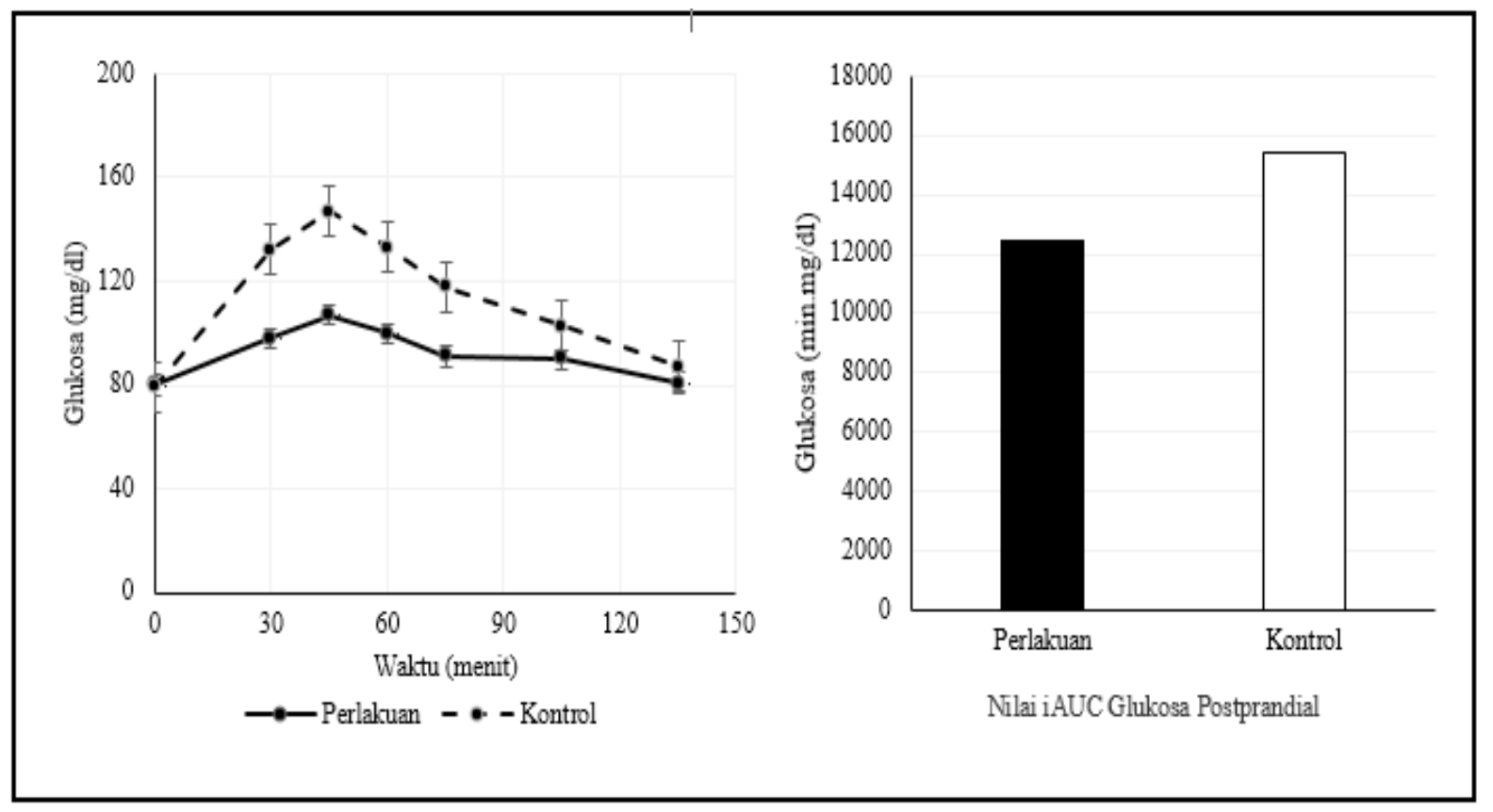

Gambar 2. Rerata Kadar Glukosa Darah Postprandial Subjek

Tabel 3. Rerata Perubahan Kadar Glukosa Postprandial Subjek pada Setiap Kelompok

\begin{tabular}{lcccccccc}
\hline \multirow{2}{*}{ Kelompok } & \multicolumn{7}{c}{ Waktu (menit) } & \multirow{2}{*}{$\mathbf{p}^{\mathbf{1}}$} \\
\cline { 2 - 8 } & $\mathbf{0}$ & $\mathbf{3 0}$ & $\mathbf{4 5}$ & $\mathbf{6 0}$ & $\mathbf{7 5}$ & $\mathbf{1 0 5}$ & $\mathbf{1 3 5}$ & \\
\hline Perlakuan & $79 \pm 5^{\mathrm{a}}$ & $98 \pm 14^{\mathrm{b}}$ & $107 \pm 12^{\mathrm{c}}$ & $99 \pm 11^{\mathrm{b}}$ & $91 \pm 8^{\mathrm{d}}$ & $89 \pm 8^{\mathrm{d}}$ & $81 \pm 10^{\mathrm{a}}$ & $0.0^{0^{*}}$ \\
Kontrol & $78 \pm 6^{\mathrm{a}}$ & $132 \pm 23^{\mathrm{b}}$ & $147 \pm 24^{\mathrm{c}}$ & $133 \pm 26^{\mathrm{b}}$ & $117 \pm 18^{\mathrm{d}}$ & $103 \pm 13^{\mathrm{e}}$ & $86 \pm 13^{\mathrm{a}}$ & $0.00^{*}$ \\
$\mathrm{p}^{2}$ & 0.53 & $0.00^{*}$ & $0.00^{*}$ & $0.00^{*}$ & $0.00^{*}$ & $0.00^{*}$ & 0.15 & \\
\hline
\end{tabular}

1) uji one way ANOVA; 2) uji paired t-test; Pada baris yang sama, angka dengan huruf sama menunjukkan tidak terdapat perbedaan yang nyata antar kelompok $(\mathrm{p}>0.05) ;{ }^{*}$ Signifikan dengan $\mathrm{p}<0.05$

mm kelompok perlakuan dan $7793,7 \pm 458$ min. mm kelompok kontrol.

Gambar 2 menunjukkan perubahan glukosa darah postprandial pada kelompok perlakuan dan kontrol. Hasil analisis pada Tabel 3 menunjukkan bahwa terdapat perbedaan signifikan rerata kadar glukosa darah postprandial pada kedua kelompok $(\mathrm{p}<0.05)$. Hasil uji lanjut menunjukkan bahwa terdapat perbedaan signifikan kadar glukosa darah postprandial pada menit ke-30 (post meal) dibandingkan pada menit ke-0 (pre meal) pada kedua kelompok. Puncak peningkatan glukosa darah postprandial pada kedua kelompok berada pada menit ke-45, dengan rerata $107 \pm 12$ $\mathrm{mg} / \mathrm{dl}$ kelompok perlakuan dan $147 \pm 24 \mathrm{mg} / \mathrm{dl}$ kelompok kontrol. Gambar 2 menunjukkan bahwa terdapat perbedaan signifikan nilai iAUC kadar glukosa postprandial antara kelompok perlakuan dan kelompok kontrol $(\mathrm{p}<0,05)$, dengan rerata nilai iAUC $12470 \pm 171,5$ menit.mg/dl kelompok perlakuan dan kelompok perlakuan sebesar $15409 \pm 380,6$ menit.mg/dl.

\section{PEMBAHASAN}

Jenis kelamin berpengaruh terhadap tingkat nafsu makan dan asupan makanan. Kecukupan energi perempuan lebih rendah dibanding dengan laki-laki, sehingga konsumsi perempuan lebih sedikit dibanding laki-laki. Berat badan berpengaruh terhadap tingkat kekenyangan individu, individu yang memiliki berat badan kurang, normal dan lebih memiliki tingkat kecukupan energi yang berbeda-beda. Penelitian yang dilakukan oleh Gregersen et al. menunjukkan bahwa tingkat rasa lapar pada perempuan lebih rendah daripada laki-laki sekitar $1 \mathrm{~cm}(10 \%) .{ }^{19}$ Berdasarkan hasil penelitian ini mengemukakan bahwa tidak terdapat perbedaan signifikan antara jenis kelamin 
kelompok kontrol dan perlakuan.

Tingkat nafsu makan diamati dengan menggunakan Visual Analog Scale (VAS) $100 \mathrm{~mm}$. Subjek membuat tanda vertikal antara dua ekstremitas, sesuai dengan yang mereka rasakan saat VAS diberikan. Tingkat nafsu makan dibagi menjadi tiga bagian yaitu tingkat rasa lapar, tingkat kepuasan, dan keinginan untuk makan. Pada kelompok perlakuan diberikan roti dan susu tinggi protein dan kelompok kontrol diberikan roti dan glukosa standar. $^{20}$

Rerata tingkat rasa lapar pada kelompok perlakuan lebih tinggi dibandingkan dengan kelompok kontrol. Status gizi sampel pada penelitian ini yaitu status gizi kurang. Jadi, pemberian susu tinggi protein pada individu yang memiliki status gizi kurang dapat meningkatkan tingkat rasa lapar. Hal ini berbeda dengan penelitian yang dilakuan oleh Buosi et al. bahwa pemberian protein pada subjek yang overweight dapat menekan rasa lapar dibandingkan dengan kontrol. ${ }^{21}$ Hal ini menunjukkan bahwa intervensi susu tinggi protein pada subjek yang memiliki berat badan kurang dapat memicu rasa lapar dibandingkan dengan kelompok kontrol, tetapi tidak berpengaruh terhadap jumlah asupan energi. Protein susu berpengaruh terhadap rasa kenyang, tetapi tidak berpengaruh terhadap asupan makan selanjutnya. Hal ini tergantung dari sumber protein, kualitas, kuantitas dan waktu pengukuran dalam penelitian tersebut. ${ }^{22,23}$

Penelitian yang dilakukan oleh Bowen et al. menunjukkan bahwa pemberian protein whey memiliki respon rasa lapar yang berbeda terhadap subjek yang memiliki berat badan normal dan berat badan lebih. ${ }^{16}$ Protein whey yang diberikan pada subjek yang memiliki berat badan lebih dapat menekan rasa lapar dibandingkan dengan subjek yang memiliki berat badan normal, hal ini dibuktikan dengan peningkatan hormon Glucagon like peptide-1 (GLP-1) yang signifikan pada subjek overweight dibanding subjek normal. GLP-1 merupakan hormon yang dihasilkan oleh usus dan jaringan adiposa, yang berperan dalam pengaturan asupan makanan dan homeostatis energi. ${ }^{24-26}$

Perbedaan respon GLP-1 terhadap orang yang memiliki berat badan berbeda, kemungkinan disebabkan oleh perbedaan sekresi GLP-1 oleh jaringan adiposa. Jaringan adiposa lebih besar pada orang yang obesitas dibandingkan dengan nor- mal dan underweight. Sekresi GLP-1 pada orang obesitas lebih besar, sehingga lebih cepat dalam memicu rasa kenyang. Sedangkan, sekresi GLP-1 pada orang yang memiliki berat badan kurang lebih sedikit, diduga tidak mampu memicu rasa kenyang dengan cepat. Hal ini diperkuat oleh Muscelli et al. bahwa efek hormon incretine termasuk GLP-1 berhubungan terbalik dengan IMT. ${ }^{27}$

Pemberian susu yang mengandung protein whey memiliki respon yang berbeda terhadap individu yang memiliki berat badan yang berbeda. Selain disebabkan oleh efek GLP-1, kemungkinan juga disebabkan oleh perbedaan metabolisme hormon-hormon yang memicu rasa lapar, misalnya ghrelin. IMT merupakan penentu konsentrasi plasma ghrelin pada manusia. Sekresi ghrelin akan meningkat pada individu yang mengalami keseimbangan energi negatif dan mengalami penurunan pada individu yang mengalami keseimbangan energi positif. ${ }^{28}$ Hal yang sama juga dikemukakan oleh Murphy dan Bloom bahwa level plasma ghrelin berhubungan terbalik dengan berat badan. ${ }^{29}$

Terdapat perbedaan rerata tingkat kepuasan pada kedua kelompok, meskipun tidak signifikan. Rerata tingkat kepuasan kelompok perlakuan lebih tinggi dibandingkan dengan kelompok kontrol. Penelitian yang dilakukan oleh Dove et al. menunjukkan hasil yang sama bahwa tidak terdapat perbedaan signifikan tingkat kepuasaan subjek yang diberikan susu dengan kontrol, meskipun tingkat kepuasaan terhadap susu cenderung lebih tinggi dibandingkan dengan kontrol. ${ }^{30}$

Ada beberapa mekanisme pengaruh protein susu terhadap tingkat nafsu makan meliputi pelepasan asam amino, kandungan peptida bioaktif dan hormon yang berpengaruh terhadap rasa kenyang. ${ }^{31}$ Anderson et al. mengemukakan mekanisme protein dalam mempengaruhi nafsu makan. Pertama, protein memulai rasa kenyang melalui pencernaan dan pelepasan Biologically Active Peptides (BAP) dalam protein. BAP ini bertindak dalam saluran pencernaan, BAP mengaktifkan reseptor, sehingga memberikan sinyal melalui saraf vagus baik secara langsung atau berinteraksi dengan hormon di usus yang terlibat dalam regulasi asupan. Kedua, asam amino bebas yang dihasilkan melalui proses pencernaan mengaktifkan sistem neurokimia, sehingga berkontribusi terhadap rasa kenyang. ${ }^{31}$ 
Tingkat nafsu makan dapat dipengaruhi oleh beberapa hal diantaranya berat badan, umur, jenis kelamin, kebiasaan makan, aktivitas fisik, dan, pengetahuan mengenai makanan. ${ }^{20}$

Penelitian oleh Frid et al. mengemukakan bahwa pemberian 18 gram protein whey ke dalam makanan yang mengandung karbohidrat lebih cepat dicerna dan diserap, mengakibatkan peningkatan konsentrasi plasma insulin dan menurunkan glukosa postprandial. ${ }^{11}$ Glukosa darah postprandial berhubungan dengan tingkat kenyang dan asupan makanan. ${ }^{33}$ Anderson et al. mengemukakan teori glucostatic yang dikembangkan oleh Mayer, bahwa fluktuasi glukosa darah memicu perubahan dalam asupan makanan. ${ }^{32}$ Rasa lapar akan dimulai jika kadar glukosa rendah dan menyebabkan rasa kenyang apabila kadar glukosa meningkat. Konsentrasi glukosa berperan penting dalam mengontrol nafsu makan karena otak bergantung dari kadar glukosa sebagai sumber energi. ${ }^{34}$

Penelitian oleh Meijl et al. bahwa pemberian susu tinggi protein dapat menurunkan kadar glukosa darah postprandial sebesar $24 \%$ dibandingkan dengan kontrol. ${ }^{35}$ Hasil yang sama juga dikemukakan oleh Kung et al. bahwa nilai iAUC pada kelompok susu tinggi protein dapat menurunkan glukosa darah postprandial lebih baik dibandingkan dengan kelompok kontrol $(\mathrm{p}<0.005) .{ }^{36}$ Salah satu manfaat protein susu yaitu merangsang pelepasan insulin dan memiliki potensi mengubah uptake glukosa dalam jaringan dan menekan fluktuasi glukosa darah postprandial. ${ }^{4}$

\section{KESIMPULAN DAN SARAN}

Nafsu makan berdasarkan tingkat rasa lapar subjek setelah diberikan susu tinggi protein mengalami peningkatan signifikan $(\mathrm{p}<0.05)$. Susu tinggi protein dapat menekan respon glukosa postprandial. Susu tinggi protein dapat menjadi salah satu alternatif untuk meningkatkan berat badan melalui pengaturan nafsu makan. Selain itu, juga dapat dijadikan usaha preventif untuk mencegah penyakit degenaratif dan penyakit infeksi, sehingga dapat meningkatkan atau mempertahankan derajat kesehatan. Saran untuk penelitian selanjutnya, untuk mengkaji lebih dalam efek pemberian susu tinggi protein terhadap hormon ghrelin dan GLP-1 yang berperan dalam pengaturan nafsu makan.

\section{DAFTAR PUSTAKA}

1. Aimutis, WR. Bioactive Properties of Milk Proteins with Particular Focus on Anticariogenesis. J.Nutr. 2004; 134(4):989S-995S.

2. Pal, S, Ellis, V, Dhaliwal, S. Effects of Whey Protein Isolate on Body Composition, Lipids, Insulin, and Glucose in Overweight and Obese Individuals. British Journal of Nutrition. 2010; 104:716-723.

3. Krissansen, GW. Emerging Health Properties of Whey Proteins and their Clinical Implications. Journal of the American College of $\mathrm{Nu}$ trition. 2007; 26(6):713S-723S.

4. McGregor RA, Poppit SD. Milk Protein for Improved Metabolic Health: A Review of the Evidence. Nutr Metab. 2013;10(46):1-13.

5. Jakubowicz D, Froy O. Biochemical and Metabolic Mechanisms by Which Dietary Whey Protein May Combat Obesity and Type 2 Diabetes. J Nutr Biochem. 2013;24(1):1-5.

6. Pistrosch F, Natali A, Hanefeld M. Is Hyperglycemia a Cardiovascular Risk Factor?. Diabetes Care. 2011;34(2): S128-S131.

7. Nilsson M, Stenberg M, Frid A, Holst JJ, Bjork IME. Glycemia and Insulinemia in Healthy Subjects after Lactoseequivalent Meals of Milk and other Food Proteins: the Role of Plasma Amino Acids and Incretins. Am J Clin Nutr. 2004;80(5):1246 -53.

8. Turner KM, Keogh JB, Clifton JM. Dairy Consumption and Insulin Sensitivity: A Systematic Review of Short- and Long-Term Intervention Studies. Nutr Metab Cardiovasc Dis. 2015;25(1):3-8.

9. Blouet C, Mariotti FO, Mikogami T, Tome D, jean-Franc, Haneau O. Meal Cysteine Improves Postprandial Glucose Control in Rats Fed a High-Sucrose Meal. J Nutr Biochem. 2007;18(8): 519-524.

10. Petersen BL, Ward LS, Bastian ED, Jenkins AL, Campbel J and Vuksan V. A Whey Protein Supplement Decreases Post-Prandial Glycemia. Bio Med Central. 2009;8(47):1-5.

11. Frid AH, Nilsson M, Holst JJ, Bjork IM. Effect of Whey on Blood Glucose and Insulin Responses to Composite Breakfast and Lunch Meals in Type 2 Diabetic Subjects. Am J Clin Nutr. 2005;82(1):9-75. 
12. Acheson, KJ, Blondel-Lubrano, A, On, SOA, Ont, MB, Ady-Azar, SE, Ammon-Zufferey, C, Monnard, I, Pinaud, S, Nielsen-Moennoz, C, Bovetto, L. Protein Choices Targeting Thermogenesis and Metabolism. Am J Clin Nutr. 2011; 93(3): 525-534.

13. Anderson, GH, Moore, SE. Dietary Proteins in the Regulation of Food Intake and Body Weight in Humans. The Journal of Nutrition. 2004; 134(4): 974S-979S.

14. Hall, WL, Millward, DJ, Long, SJ, Morgan, M. Casein and Whey Exert Different Effects on Plasma Amino Acid Profiles, Gastrointestinal Hormone Secretion and Appetite. British Journal of Nutrition. 2002; 89:239-248.

15. Vendhorst MAB, Nieuwenhuizen AG, Hochstenbach-Wealen A, Vught AJAHV, Westertep KR, Engelen MPKJ, Brummer RM, Deutz NEP, Westertep-Plantenga MS. Dose-Dependent Satiating Effect of Whey Relative to Casein or Soy. Physio Behav. 2009;96(4-5): 675-682.

16. Bowen, J, Noakes, M, Clifton, PM. Appetite Regulatory Hormone Responses to Various Dietary Proteins Differ by Body Mass Index Status Despite Similar Reductions in ad Libitum Energy Intake. The Journal of Clinical Endocrinology dan Metabolism. 2006; 91(8):2913-2919.

17. Lameshow, S, Hosmer, DW, Klar, J, Lwanga, SK. Besar Sampel dalam Penelitian Kesehatan. Yogyakarta: Gadjah Mada University Press; 1997

18. Olli, K, Salli, K, Alhoniemi, E, Saarinen, M, Ibarra, A, Vasankari, T, Rautonen, N, Tiihonen, K. Postprandial Effects of Polydextrose on Satiety Hormone Responses and Subjective Feelings of Appetite in Obese Participants. Nutrition Journal. 2015;14(2):1-12.

19. Gregersen N, et al. Determinants of Appetite Ratings: the Role of Age, Gender, BMI, Physical Activity, Smoking Habits, and Diet/Weight Concern. Food \& Nutrition Research. 2011 55(1):1654-6628

20. Benelam, B. Satiation, Satiety and Their Effects on Eating Behaviour. British Nutrition Foundation Nutrition Bulletin. 2009; 34(2):126-173.

21. Buosi, W, Bremner, DM, Horgan, GW, Fyfe,
CL, Johnstone, AM. Effect of High-Protein Breakfast Meals on within Day Appetite and Food Intake in Healthy Men and Women. Food and Nutrition Sciences. 2015;6(3):386390

22. Anderson, GH, Luhovvy, Akhavan, T, Panahi, S. Milk Proteins in the Regulation of Body Weight, Satiety, Food Intake and Glycemia. Physiologic Functions of Milk Proteins. 2011; 67:147-159.

23. Diepvens, K, Berer, H, Plantenga, W. Different Proteins and Biopeptides Differently Affect Satiety and Anorexigenic/Orexigenic Hormones in Healthy Humans. International Journal of Obesity. 2008;32:510-518.

24. Bloom, SR, Kuhajda, FR, Laher, L, Pi-Sunyer, X, Ronnett, GV, Tan, TMM, Weigle, DS. The Obesity Epidemic: Pharmacological Challenges. Mol Interv. 2008;8(2):82-98

25. Moran, TH, Dailey, MJ. Gut Peptides: Targets for Antiobesity Drug Development?. Endocrinology. 2009;150(6):2526-2530.

26. Madsbad, S. The Role of Glucagon-Like Peptide-1 Impairment in Obesity and Potential Therapeutic Implications. Diabetes, Obesity and Metabolism. 2014; 16(1): 9-21.

27. Muscelli, E, Mari, A, Casolaro, A, Camastra, S, Seghieri, G, Gastaldelli, A, Holst, JJ, Ferrannin, E. Separate Impact of Obesity and Glucose Tolerance on the Incretin Effect in Normal Subjects and Type 2 Diabetic Patients. BMJ. 2008;57(5):1340-1348.

28. Shiiya, T, Nakazato, M, Mizuta, M, Date, Y, Mondal, MS, Tanaka, M, Nozoe, S, Hosoda, H, Kangawa, K, Matsukura, S. Plasma Ghrelin Levels in Lean and Obese Humans and the Effect of Glucose on Ghrelin Secretion. The Journal of Clinical Endocrinology \& Metabolism. 2002;87(1):240-244.

29. Murphy, KG, Bloom, SR. Gut Hormones in the Control of Appetite. Exp Physiol. 2004; 89(5):507-516.

30. Dove, ER, Hodgson, JM, Puddey, IB, Beilin, LJ, Lee, YP, Mori, TA. Skim Milk Compared with A Fruit Drink Acutely Reduces Appetite and Energy Intake in Overweight Men and Women. Am J Clin Nutr. 2009;90(1):70-75.

31. Luhovvy, BL, Akhavan, T, Anderson, GH. Whey Proteins in the Regulation of Food 
Intake and Satiety. J Am Coll Nutr. 2007; 26(6):704S-712S.

32. Anderson, GH, Aziz, A, Samra, RA. Physiology of Food Intake Regulation: Interaction with Dietary Components. Protein and Energy Requirements in Infancy and Childhood. Nestlé Nutr Workshop Ser Pediatr Program. 2006; 58: 133-145.

33. Akhavan T, Luhovyy BL, Anderson GH. Effect of Drinking compared with Eating Sugars or Whey Protein on Short-Term Appetite and Food Intake. Int J Obes. 2011;35:562-569.

34. Marty N, Dallaporta M, Thorens B. Brain Glu- cose Sensing, Counter Regulation, and Energy Homeostatis. Physiology.2007;22(4):241-251.

35. Meijl LV, Mensink RP. Effects of Milk and Milk Constituents on Postprandial Lipid and Glucose Metabolism in Overweight and Obese Men. Br J Nutr. 2013;110(3):413-419.

36. Kung B, Pare S, Tucker AJ, Anderson GH, Wright AJ, Goff D. Effect of Milk Protein Intake and Casein: Whey Ratio in Breakfast Meals on Postprandial Glucose, Satiety Ratings and Subsequent Meal Intake. JAS. 2016;94(5):243-248. 